\title{
Effect of Leucaena leucocephala, as a protein source in a total mixed ration, on milk yield and composition of Saanen milk goats
}

\author{
K. Leketa, E.F. Donkin, A. Hassen \& A.M. Akanmu \\ Department of Animal and Wildlife Sciences, University of Pretoria, X20 Hatfield 0028, Pretoria, South Africa
}

(Received 20 September 2017; Accepted 21 February 2019; First published online 14 April 2019)

\author{
Copyright resides with the authors in terms of the Creative Commons Attribution 4.0 South African Licence. \\ See: http://creativecommons.org/licenses/by/4.0/za \\ Condition of use: The user may copy, distribute, transmit and adapt the work, but must recognise the authors and \\ the South African Journal of Animal Science.
}

\begin{abstract}
This study examined the effects of diets with two protein sources (oilseed cake meal (OSCM) and Leucaena leucocephala hay) on the performance of lactating goats that were fed a total mixed ration (TMR). Thirty Saanen milk goats were divided into two groups, which were fed one of the two TMRS, with or without Leucaena hay at $25 \%$ of the DM. The TMRs were formulated to be iso-nitrogenous, iso-energetic and isoneutral detergent fibre, while using two sources of crude protein, namely i) Leucaena hay; and ii) oilseed cake meal OSCM from soybean, sunflower, and cottonseed. No significant differences were revealed in body condition score, bodyweight change, milk yield and milk composition, such as milk fat (\%), milk lactose (\%), somatic cell count $\left(\times 10^{3}\right.$ cells $\left./ \mathrm{mL}\right)$ and milk protein (\%) during the entire lactation period. In contrast, goats fed the TMR with Leucaena hay had a lower milk urea nitrogen (mg nitrogen/dL) level than those fed the control diet (with OSCM). It was concluded that replacing a proportion of oilseed cake meal with Leucaena in Saanen milk goats fed TMR does not negatively influence milk production and composition.
\end{abstract}

Keywords: fodder tree, oilseed cake, protein concentrate, somatic cell count

\# Corresponding author: Abubeker.hassen@up.ac.za

\section{Introduction}

The dairy goat industry is fast gaining popularity in developing counties owing to its characteristic smaller fat globules, which make it more digestible than cow's milk (Jabbar et al., 2006), its increased demand for cheese making (Jaubert \& Kalantzopoulos, 1996) and its exceptional benefits when fed to children who are allergic to milk from other sources (Fisberg et al., 2000). Goat milk plays an important role socially and economically for many households in rural communities (Shinde et al., 2000). Goat milk production has the potential to alleviate poverty and reduce malnutrition, especially in children and people living with HIV (Peacock, 2005). Dairy goats, in contrast to other dairy animals, are relatively small and are easily handled by women and children, are less expensive to maintain, as they require lesser volume of feed compared with cows, reproduce quickly and can produce an adequate quantity of milk for households (Donkin, 1997). However, the main source of milk in South Africa for urban and peri-urban communities is dairy cows, although it requires expensive maintenance in terms of feeds and management and a large area for grazing, and is quite demanding on small households (Donkin, 2000). However, the optimum production of goat milk in rural areas is faced with poor nutrition, which is characterized by poor animal feeds and escalating prices of commercial feeds, which are not affordable to small-scale farmers. This reduces the potential of dairy goats to produce a large amount of good-quality milk. Under these circumstances, practical supplements may include fodder from trees such as Vachellia tortilis and Leucaena leucocephala. The forages of these trees can be incorporated in the diet of milk goats as a protein and roughage supplement to reduce the cost of feeding. However, the limited information about the use and chemical composition of Leucaena for small-scale farmers might be a constraint to its use. Although Leucaena has been reported to be highly palatable, the toxic mimosine content poses a challenge to its use in animal feeding (Sastry \& Singh 2008). One of the strategies to reduce the toxic effect of Leucaena is treatment with Synergistes jonesii, which was introduced in South Africa in the 1990s to reduce Leucaena forage toxicity (Meissner, 1997). A practical strategy to overcome Leucaena toxicity for rural communities is to minimize the level of Leucaena consumed by the animals per day. 
Several studies have been conducted to determine the effect of Leucaena supplementation on bodyweight gain (Ha et al., 1995; Rubanza et al., 2006) and milk production of dairy cows (Waipanya \& Srichoo, 1998). No significant effect was witnessed in terms of live weight, body condition, milk yield and milk composition compared with the control when dairy cows consumed $503 \mathrm{~g}$ DM Leucaena per day (PenicheGonzalez et al., 2014). This study was carried out to determine the potential effect of Leucaena on yield and quality of goat milk when included in a total mixed ration (TMR), and may be relevant to rural communities of South Africa who face high feed costs. Smallholder farmers may be able to use goat milk and meat as a source of protein and income through selling the surplus. This study compared the performance of milk goats fed TMR containing Leucaena as source of protein with TMR formulated with oilseed cake meal (OSCM).

\section{Materials and Methods}

The experiment was conducted from October 2008 to April 2009 at Hatfield Research Farm of the University of Pretoria. Thirty Saanen milk goats in their first, second and third lactations were used in this trial. Initial bodyweight of the animals was $54.8 \pm 1.95 \mathrm{~kg}$. The goats were divided into 10 groups of three goats per group, balanced for age, parity, bodyweight and milk yield. A complete randomized block design was used in this experiment with two treatments diets being allocated to each group of three animals. Each treatment was replicated five times, resulting in 30 experimental units. The health of the goats was monitored throughout the study and no cases of the effects of mimosine were noticed.

The two experimental diets were formulated to be iso-energetic, iso-nitrogenous and iso-neutral detergent fibre (Tables 1 \& 2) using two sources of crude protein, namely i) OSCM, composed of soybean, sunflower and cottonseed meal; and ii) Leucaena hay. The feeds were formulated according to the Langston University Goat Research and Extension programmes (2000) and balanced to achieve the required nutrient concentration for lactating goats with a moderate yield (NRC, 2007). Both experimental diets contained $14 \%$ crude protein (CP) and 51\% neutral detergent fibre (NDF) of dry matter (DM). Leucaena was harvested during summer and autumn, and dried and chopped with a hammer mill through a 25-mm diameter sieve. The experimental diets were mixed thoroughly and fed to the animals as a TMR to minimize selection by the goats and maximize the intake of the roughages. Each goat in both treatment groups was offered TMR at $4.6 \%$ of bodyweight fed in two equal portions (8:00 and 15:00) and the goats had ad libitum access to fresh water every day (Table 1 ).

Table 1 Ingredients and chemical composition of total mixed ration ( $\mathrm{g} / \mathrm{kg}$ DM basis) fed to Saanen milk goats

\begin{tabular}{lcc}
\hline \multirow{2}{*}{ Parameters } & \multicolumn{2}{c}{ Treatment $^{{ }^{1}}$} \\
\cline { 2 - 3 } & TMR including Leucaena & TMR including OSCM \\
\hline Ingredients (\%) & & \\
Yellow maize meal & 22.0 & 27.0 \\
Eragrostis curvula & 18.0 & 30.0 \\
Leucaena & 25.0 & 0.0 \\
Wheat bran & 8.0 & 8.0 \\
Cottonseed oil cake meal & 9.0 & 11.0 \\
Sunflower oil cake meal & 9.0 & 11.0 \\
Full fat soybean meal & 0.0 & 4.0 \\
Molasses meal & 7.0 & 7.0 \\
Mineral mix & 2.0 & 2.0 \\
Chemical composition (\%) & & 15.0 \\
Crude protein & 15.0 & 15.7 \\
Crude fibre & 16.8 & 62.0 \\
Total digestible nutrients & 60.0 & \\
\hline
\end{tabular}

TMR: total mixed ration; OSCM: oil seed cake meal

${ }^{1}$ Feeds were formulated as described by Langston University Goat Research and Extension programs (2000) 
Table 2 Chemical composition of concentrate formulated with oil seed cake meal and/or Leucaena as protein source fed to milk goats

\begin{tabular}{lccccccc}
\hline \multirow{2}{*}{ Item } & \multicolumn{7}{c}{ Nutrient g/kg DM } \\
\cline { 2 - 8 } & CP & NDF & ADF & ADL & Ash & Ca & P \\
\hline & & & & & & & \\
Leucaena & 13.6 & 51.8 & 27.7 & 7.1 & 7.2 & 0.76 & 0.4 \\
Control & 13.5 & 50.4 & 27.4 & 6.2 & 6 & 0.79 & 0.45 \\
SEM & \pm 0.13 & \pm 0.74 & \pm 0.18 & \pm 0.18 & \pm 0.14 & \pm 0.06 & \pm 0.02 \\
\hline
\end{tabular}

CP: crude protein; NDF: neutral detergent fibre; ADF: acid detergent fibre; ADL: acid detergent lignin; Ca: calcium;

$\mathrm{P}$ : phosphorus. SEM: standard error of mean

The goats were milked twice a day in the morning and afternoon using a pipeline milking machine and milk yield was recoded daily.

Leucaena was harvested three times during the growing season and dried before use. The first Leucaena forages were harvested in autumn 2008 at the end of growing season. The second and third Leucaena forages were harvested in summer in January and March 2009, respectively. The third harvesting at March 2009 was done at a 100\% podding stage. After harvesting, the forages were dried by exposing them to the sun (sun dried) or placing them in shade (air dried). The harvested and dried components were later stored in an old animal shed with open windows and entrance to provide sufficient ventilation. The shelter was well roofed, which kept it dry and gave good ventilation. The dried forages were left under the shed until required to formulate the TMR.

After drying, the edible plant components were separated carefully from the branches and sorted into leaves, pods and twigs. The twigs and small stems at $<3 \mathrm{~mm}$ in diameter were regarded as part of the shoots as it was assumed that goats would consume this component without restriction. About $100 \mathrm{~g}$ representative samples of the edible components of the Leucaena plant were milled separately for chemical analysis at the Nutrition Laboratory, University of Pretoria. Each plant component was analysed for DM, ash, organic matter, nitrogen, CP, NDF, acid detergent fibre, acid detergent lignin, calcium and phosphorus concentration. All samples were analysed in duplicate to estimate analysis error. Where differences between duplicates exceeded $5 \%$, the analysis was repeated until differences of less than $5 \%$ were achieved. The remaining plant components were mixed thoroughly and used as part of the TMR during the feeding trial.

The other ingredients were purchased on the local market. Eragrostis hay and Leucaena forages were chopped with a hammer mill with a 25-mm diameter sieve and incorporated with the concentrates with a feed mixer to reduce feed selectivity. In addition, representative samples of these feeds were collected weekly in labelled plastic bags for each diet, mixed, and used as sub-samples for subsequent chemical analysis.

Goats were milked in a milking parlour with a facility to milk six goats at a time. Milk yield was measured with Waikato milk meters during milking. The goats were milked twice a day between 07:00 and 09:00 in the morning and 14:00 and 15:00 in the afternoon. The first animals to be milked in the morning were also the first to be milked in the afternoon and milk yield was recorded manually at every milking.

Milk samples from two consecutive morning and afternoon milkings were collected monthly for seven months from the milk meter to small bottles $(50 \mathrm{~mL})$ that contained preservative. The samples were transported to the Lactolab at Irene, Pretoria, and analysed for milk fat, lactose, protein, somatic cell count and milk-urea nitrogen (MUN) with a MilkoScan (Foss Electric, Hillerød, Denmark).

The body condition score (BCS) and bodyweight of goats were assessed fortnightly throughout the experiment. BCS was used to indicate the fat reserves during lactation as this is the period of high energy demand. The score used ranged from 1.0 to 5.0 and half scores were used as intermediate points, as described by Santucci at el. (1991). BCS was used to estimate fat cover in the lumber region and the brisket fatpad.

The effects of the TMR on milk yield and quality were analysed by the procedure of SAS (2000) for completely randomized blocked designs. The animals were blocked for the effect of parity, age and BCS. Values with $P<0.05$ were deemed significant. 


\section{Results}

The results for the milk yield of goats fed TMR with or without Leucaena are presented in the Table 3. There were no significant differences $(P>0.05)$ between goats fed TMR with or without Leucaena in terms of milk yield, milk fat yield and milk protein yield.

Table 3 Mean values for the milk yield from Saanen milk goat fed total mixed ration with or without Leucaena

\begin{tabular}{lcccc}
\hline Yield (g/day) & Leucaena TMR & Control TMR & SEM & $P$-value \\
\hline Milk yield & 1670 & 1630 & \pm 0.09 & 0.9398 \\
Milk fat yield & 107 & 101 & \pm 0.07 & 0.8435 \\
Milk protein yield & 100 & 95 & \pm 0.02 & 0.7894 \\
\hline
\end{tabular}

TMR: total mixed ration. SEM: standard error of mean

Average milk yield trends from the two treatment groups are illustrated in Figure 1. Milk yield increased gradually in the second and third months, then declined steadily in the last four months. Peak milk yield occurred in the second and third months with a mean of 2 and $2.4 \pm 0.16 \mathrm{~L}$ for goats fed the control and the Leucaena diets, respectively. The mean daily milk yield of animals fed TMR without Leucaena appeared to be higher in the first two months than during the fifth and sixth months compared with the animals that were fed the TMR with the Leucaena diet. However, goats fed TMR with Leucaena appeared to produce higher milk yield than those fed the control diet (with OSCM) during the third, fourth and last months. But the differences observed in all these periods were not significant $(P>0.005)$. Milk yield had a moderate positive correlation with months in milk $\left(R^{2}=0.48\right.$ and 0.57$)$ for goats fed the Leucaena and control diets, respectively.

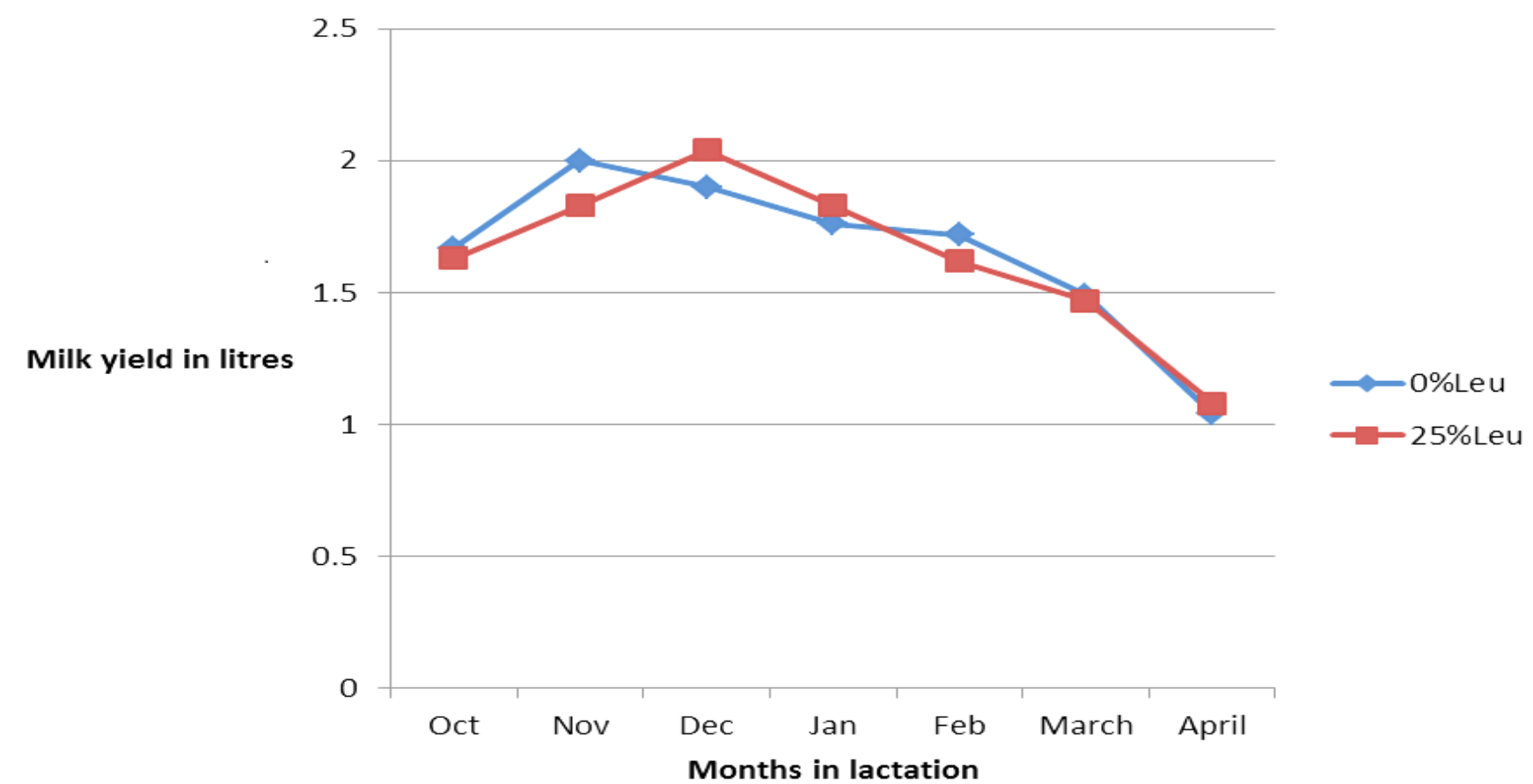

Figure1 Complete lactation curves for Saanen milk goats fed total mixed ration with or without Leucaena

Milk produced during the seven months of lactation was analysed for milk fat, protein, lactose and MUN (Table 4). Inclusion of Leucaena in the TMR had no significant $(P>0.05)$ effect on milk fat produced by goats fed the Leucaena diet and control group on either morning (2.5 vs $2.4 \pm 0.09 \%)$ or afternoon (3.9 vs $3.8 \pm 0.10 \%)$ milkings. 
Table 4 Chemical composition of milk from Saanen goats fed total mixed ration with or without Leucaena

\begin{tabular}{|c|c|c|c|c|c|}
\hline \multirow{2}{*}{ Parameters } & \multirow{2}{*}{ Time } & \multicolumn{2}{|c|}{ Treatments } & \multirow{2}{*}{ SEM } & \multirow{2}{*}{ Effect } \\
\hline & & TMR with Leucaena & Control TMR & & \\
\hline \multicolumn{6}{|l|}{ Milk composition } \\
\hline \multirow[t]{2}{*}{ Milk fat (\%) } & am & 2.50 & 2.40 & 0.090 & NS \\
\hline & $\mathrm{pm}$ & 3.90 & 3.80 & 0.100 & NS \\
\hline \multirow[t]{2}{*}{ Milk protein (\%) } & am & 3.00 & 2.80 & 0.050 & * \\
\hline & $\mathrm{pm}$ & 3.00 & 2.90 & 0.060 & NS \\
\hline \multirow[t]{2}{*}{ Milk lactose (\%) } & am & 4.50 & 4.40 & 0.050 & NS \\
\hline & $\mathrm{pm}$ & 4.30 & 4.40 & 0.050 & NS \\
\hline \multirow[t]{2}{*}{ Milk urea nitrogen (mg N/dL) } & am & 25.00 & 28.30 & 0.560 & $\star *$ \\
\hline & $\mathrm{pm}$ & 26.20 & 29.90 & 0.510 & $\star *$ \\
\hline \multirow[t]{2}{*}{$\operatorname{scC}(x 1000)$} & am & $1.50 \times 10^{3}$ & $2.1 \times 10^{3}$ & 446.700 & NS \\
\hline & $\mathrm{pm}$ & $3.70 \times 10^{3}$ & $4.4 \times 10^{3}$ & 699.600 & NS \\
\hline \multicolumn{6}{|l|}{ Weighted averages } \\
\hline Milk fat (\%) & & 2.84 & 2.82 & 0.050 & NS \\
\hline Milk protein (\%) & & 2.90 & 2.89 & 0.040 & NS \\
\hline Milk lactose (\%) & & 4.44 & 4.35 & 0.030 & NS \\
\hline
\end{tabular}

Means with different superscript $\left({ }^{a, b}\right)$ along the same rows differ significantly $(P<0.01)$

NS: not significant, ${ }^{\star} P<0.05,{ }^{\star \star} P<0.01$

TMR: total mixed ration. SEM: standard error of mean

Milk produced by goats fed TMR with Leucaena had a significantly higher $(P<0.05)$ protein content compared with that of goats fed the control diet (3.0 vs $2.8 \pm 0.05 \%)$ for milk obtained in the morning (Table 4). In contrast, there was no difference $(P>0.05)$ in terms of milk protein obtained from goats fed both TMR diets at the afternoon milking. No significant $(P>0.05)$ effect was recorded in milk lactose percentages for both treatments, either in the morning or afternoon.

The inclusion of the Leucaena in the TMR had a beneficial effect on MUN by reducing it when compared to the milk from goats fed the control diet. Slightly lower MUN values were observed both in the morning and afternoon for the goats fed TMR with Leucaena compared with those fed the control diet with OSCM.

The milk composition of Saanen milk goats fed TMR with or without Leucaena as affected by time of milking is presented in Table 4. Milk composition differed between the morning and the afternoon milk produced by the goats fed TMR with or without Leucaena. The milk produced in the afternoon had significantly higher $(P<0.01)$ fat, MUN concentration and somatic cell counts than the milk produced in the morning for both groups. In contrast, the time of milking had no influence on milk lactose and milk protein composition.

The BCS of the milk goats, which were measured every two weeks throughout the seven-month lactation period, are shown in Table 5. The average results for BCS and body weights are presented in Table 6 , and the BCS trends during the lactation period are shown in Figure 2. There was no significant differences $(P>0.05)$ between animals fed Leucaena diet and control diet in terms of BCS and BW. Figure 2 shows that BCS of animals in both groups increased linearly with time. There was a positive correlation $\left(R^{2}=0.98\right.$ and $\mathrm{R}^{2}=0.90$ ) between time and BCS for goats fed Leucaena and control diets, respectively. During the first lactation month (October) there were slightly higher scores for goats fed Leucaena diets compared with control. The goats fed Leucaena diets appeared to have higher BCS than goats fed the control diet from the third month until the last month, but these differences were not significant $(P>0.05)$. 
Table 5 Body condition scoring of Saanen goats fed total mixed ration with or without Leucaena

\begin{tabular}{lcccc}
\hline Treatment & Leucaena diet & Control diet & SEM & Effect \\
\hline BCS & 2.40 & 2.3 & \pm 0.11 & NS \\
BW (kg) & 53.40 & 56.1 & \pm 2.78 & NS \\
IW (kg) & 50.30 & 56.1 & \pm 2.82 & NS \\
FW (kg) & 57.30 & 58.1 & \pm 2.75 & NS \\
TG (kg) & $7.00^{\mathrm{a}}$ & $2.13^{\mathrm{b}}$ & \pm 0.83 & $\star \star *$ \\
\hline
\end{tabular}

\footnotetext{
${ }^{\mathrm{ab}}$ Means with different superscript letters in the same row differ highly significantly $(P<0.0001)$

${ }^{1}$ Means the score ranged from 1.0 to 5.0

BCS: body condition score, BW: body weight. IW: initial weight. FW: final weight. TG: total gain SEM: standard error of mean
}

Table 6 Mean monthly values for weight changes of lactating goats fed total mixed ration with or without Leucaena

\begin{tabular}{lccccc}
\hline \multirow{2}{*}{ Time in Months } & \multicolumn{2}{c}{ Treatment } & \multirow{2}{*}{ SEM } & P-value & \multirow{2}{*}{ Effect } \\
\cline { 2 - 3 } & Leucaena & Control & & & \\
\hline October & 50.5 & 55.9 & \pm 3.03 & 0.2126 & NS \\
November & 52.0 & 56.5 & \pm 2.08 & 0.2935 & NS \\
December & 52.1 & 54.7 & \pm 1.97 & 0.5117 & NS \\
January & 55.5 & 53.2 & \pm 1.94 & 0.5665 & NS \\
February & 54.1 & 56.2 & \pm 1.9 & 0.5926 & NS \\
March & 55.2 & 56.7 & \pm 1.91 & 0.7061 & NS \\
April & 57.6 & 56.7 & \pm 1.91 & 0.8174 & NS \\
\hline
\end{tabular}

NS: Not significant. SEM: standard error of mean

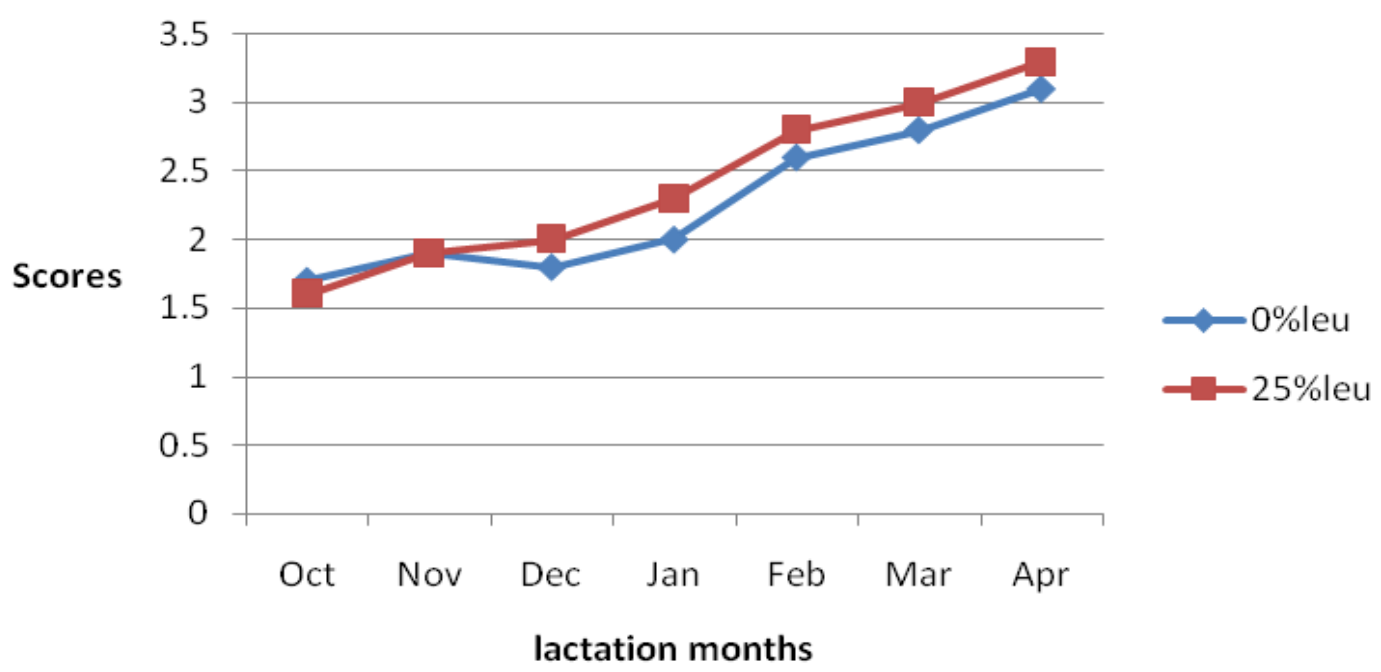

Figure2 Mean body condition scores for lactating goats fed total mixed ration with and without Leucaena 
There was no significant difference $(P>0.05)$ between animals fed a TMR with the Leucaena and TMR with OSCM in terms of average bodyweight and bodyweight gain (Table 6 ). The weight of the goats increased slightly from the fourth month until the last month of the experimental period.

\section{Discussion}

Dairy goats have a high demand for nutrients during late gestation and lactation, and therefore consume more feed to supply this nutrient requirement (NRC, 2007). Malnutrition during these periods can lead to ketosis and milk fever, while overfeeding and insufficient roughage intake can result in acidosis (NRC, 2007). To avoid these metabolic disorders, diets in this study were formulated to meet the nutrient requirements of lactating goats and balanced to be iso-energetic, iso-nitrogenous and iso-neutral detergent fibre (NRC, 2007). A TMR is usually formulated to help improve feed intake, especially roughage, to meet the nutritional requirements of the animal and to reduce the risk of acidosis. Both TMRs formulated for this study provided approximately calculated value of metabolizable energy $(600 \mathrm{~g} / \mathrm{kg})$ and CP $(14 \%)$. Owing to the relatively low level of CP and soluble nutrients in Eragrostis curvula hay, which served as the main source of roughage in the control diet, its inclusion was limited to $30 \%$ to meet nutritional needs during lactation.

Milk yields recorded for goats on both TMR diets were similar, although lower than those reported in other studies involving Saanen milk goats (Stella et al. 2007). Stella et al. (2007) recorded milk yields of ( 2.38 vs. $2.08 \pm 0.14 \mathrm{~kg} /$ day) for Saanen goats fed TMR supplemented with live Saccharomyces cerevisiae and those on the control diet. Laudadio \& Tufarelli (2010) recorded a milk yield of over $2.2 \pm 0.05 \mathrm{~kg} / \mathrm{day}$ for Jonica dairy goats fed TMR with partially different rumen digestible protein. Lower milk yield was observed in this study because about one third of the goats were in their first lactation and produced relatively less milk throughout lactation, which could have affected the overall mean. The goats in their second and third lactations produced higher amounts of milk with means of (2.3 and $2.1 \pm 0.12$ litres/d), respectively. However, Laudadio \& Tufarelli (2010) used only multiparous lactating Jonica dairy goats and Stella et al. (2007) included only eight primiparous goats out of a total of 36 animals. Donkin (1997) recorded lower milk yields for goats in their first lactation in $1989(1.92 \pm 0.3 \mathrm{~kg} / \mathrm{d})$ and these increased in the second lactation $(2.48 \pm 0.39 \mathrm{~kg} / \mathrm{d})$.

The goats fed the TMR with Leucaena appeared to produce less milk during the initial stages of the experiment. This might be attributed to the lower feed intake for goats in this group at this time as the TMR contained a relatively high proportion of pods and twigs. This was in agreement with the study by Maasdorp et.al. (1999), which showed a lower feed intake of a diet that included fodder trees (Vachellia boliviana, Calliandra calothyrsus, and Leucaena leucocephala) during the adaptation period, but this increased steadily with time as the animals adapted to the diet. During the adaptation of the animals in this study, all the goats were fed the TMR, which was later used as control diet during the experiment. The animals fed TMR with Leucaena had to adjust to the new feed, while the goats fed the control diet were already used to their diet. During the third and the fourth months of the trial the milk yields from goats fed the Leucaena diet appeared to be higher than the yields from goats fed the control diet, but not significantly different. Higher values obtained for goats fed TMR containing Leucaena could be due to higher organic matter digestibility of Leucaena compared with Eragrostis curvula in the control diet. In a similar study, Steinshamn (2010) reported increased milk yield when dairy cows were fed diets containing grassland legume species, Trifolium repens. The author reported that the increased milk yield resulted from higher apparent digestibility, organic matter, NDF and hemicellulose, which were greater than diets without legumes. Leucaena has been found to be a rich source of $\mathrm{CP}$ and minerals. The amino acid pattern of Leucaena is comparable with that of soya bean and fishmeal, which makes it an almost complete ruminant feed (Sethi \& Kulkarni, 1995). These properties in Leucaena could be responsible for the higher milk yield recorded for dairy goats on TMR with Leucaena in this study. The results of this study confirm that rumen microbes are able to tolerate low to moderate inclusion of Leucaena in the diet because no adverse effects were observed. Liener (2003) reported that ruminants are able to convert greater amounts of Leucaena before it becomes toxic to their system. Ruminants can develop resistance to mimosine toxicity, depending on the microbial population in the rumen. The author added that Australian ruminants become more resistant to mimosine toxicity because of the presence of bacteria that are capable of detoxifying mimosine in their rumen.

Because no significant effects were witnessed in the milk yield for both treatments, this proves the hypothesis that the inclusion of Leucaena in the TMR for milk goats has no adverse effects on milk production and might improve milk yield. Feeding Leucaena has been reported in dairy cows (Maasdorp et al, 1999; Waipanya \& Srichoo, 1999), in dairy goats (Richards et al., 1994), and indigenous goats (Akingbade et al., 2004).

This study also showed that there were no differences between goats fed the TMR diet with or without Leucaena in terms of milk fat (\%), milk lactose (\%), somatic cell counts (x 103) and milk protein (\%). This concurs with other studies, which showed that Leucaena had no negative effects on milk fat and protein for 
dairy goat (Richards et al., 1994). However, there are contrasting reports to these findings by Akingbade et al. (2004) in terms of protein and lactose percentage on South Africa Nguni goats.

Less MUN produced by goats fed TMR with Leucaena compared with those fed the control diet might be attributed to the nutritional factors that affect milk urea, including feed intake, feed protein and the protein to energy ratio in the diet (Geerts et al. 2004). Hof et al. (1997) stated that the concentration of urea in milk is a parameter that can be used to detect feeding imbalances. Urea in milk reflects the protein content of diets and results could be related to an excess of protein intake during grazing or feeding (Braghieri et al., 2006). The increase of urea in milk has been associated with insufficient energy supply, as urea is formed because protein is used for gluconeogenesis (Schepers \& Meijer, 1998). Cabiddu et al. (1999) indicated that increased urea content in milk was correlated for an excess of protein in the ration when Saanen goats were stall fed with hay and concentrates. In this study, it was observed that the goats fed the control diet were more selective and tended to select the concentrates rather than roughage, whereas goats fed TMR with Leucaena were not selective. This confirmed studies by other researchers (Mtenga \& Shoo, 1990; Nyambati et al., 2006). These authors found that Leucaena increased feed intake and resulted in better utilization of forage. However, in this experiment both groups had higher MUN than the results recorded by Laudadio \& Tufarelli (2010), ( 21.7 to $23.1 \pm 0.2 \mathrm{mg} / \mathrm{dL}$ ), who studied Jonica dairy goats fed pelleted diets. The readings were higher than target range suggested by Jonker et al. (1999) of $10-16 \mathrm{mg} / \mathrm{dL}$.

Body condition score did not follow the same pattern as milk production. This response was also reported by Stella et al. (2005) in dairy goats where the treated animals and the control group did not deteriorate despite high milk production. There was no significant weight change throughout this experiment, and this remained similar for animals fed Leucaena and the control diet throughout the experiment. Similar findings were also reported by Richards et al. (1994). No clinical symptoms that could be related to mimosine were manifested during this study. The goats appeared healthy in both groups throughout the study, except for a few goats that developed mastitis, but this was not associated with the inclusion of Leucaena in the diet, as they were among the goats in both groups. The presence of mimosine and dynamic high pressure in milk and blood was not measured in the present study owing to limited time and resources. The presence and level of mimosine in the milk and blood serum in Saanen dairy goats fed TMR with Leucaena in South Africa still needs to be established, as it has been done elsewhere (Gupta et al., 1999).

\section{Conclusion}

This study has shown that replacing a proportion of OSCM with 25\% Leucaena forage as protein source in the TMR fed to Saanen milk goats does not negatively influence milk yield, milk composition, bodyweight and condition of Saanen milk goats. However, the inclusion of Leucaena in a TMR diet fed to Saanen goats was shown to reduce the amount of urea in the milk, indicating efficient use of nitrogen from Leucaena ingested by milk goats compared with OSCM as protein source. Thus, smallholder farmers in South Africa are able to reduce the feeding cost of milk goats by planting Leucaena on their farms and utilizing the hay as part of TMR.

\section{Acknowledgement}

The project was financially supported by the Department of Agriculture Forestry and Fisheries (DAFF) and its contribution made the successful completion of this study. We would also like to express our sincere gratitude to the staff of Hatfield Research Farm, Nutrilab in the Department of Animal and Wildlife Science and Lactolab, Irene (ARC) for their assistance.

\section{Authors' Contributions}

$\mathrm{KL}$, $\mathrm{EFD}$ and $\mathrm{AH}$ designed the experiments. $\mathrm{KL}$ collected the data, analysed and interpreted the data under supervision of EFD and AH. KL drafted the manuscript. EFD, AH and AMA improved the manuscript by editing it.

\section{Conflict of Interest Declaration}

There are no conflicts of interest.

\section{References}

Akingbade, A.A., Nsahlai I.V. \& Morris, C.D., 2004. Reproductive performance, colostrum and milk constituents of mimosine-adapted South Africa Nguni goats on Leucaena leucocephala grass or natural pastures. Small Rumin. Res. 52, 253-260.

Braghieri, A. Pacelli, C. Verdone, M. Girolami, A \& Napolitano, F., 2007. Effect of grazing and homeopathy on milk production and immunity of Merino derived ewes. Small Rumin. Res. 69, 95-102.

Cabiddu, A., Branca, A., Decandia, M., Pes, A., Santucci, P.M., Masoero, F. \& Calamari, L., 1999. Relationship between body condition score, metabolic profile, milk yield and milk composition in goats browsing a Mediterranean shrubland. Livest. Prod. Sci. 61, 267-273. 
Donkin, E.F., 1997. Productivity and diseases of Saanen, indigenous and crossbred goats on zero grazing. PhD thesis, Faculty of Veterinary Science, Medical University of South Africa. (http://upetd.up.ac.za/thesis/available/etd)

Donkin, E.F. \& Bayazoglu, P.A., 2000. Milk production from goats for households and small-scale farmers in South Africa. Proceedings 7th International Conference on Goats. France. May. pp. 324-326.

Fisberg, M., Ferreira, A.M.A., Nogueira, M. \& Fisberg, R.M., 2000 Acceptance and tolerability of goat milk in preschool children. Proceedings 7th International Conference on Goats, Tours, France. 15-18 May 2000, 613.

Jabbar, A., Saddiqi, H.A. \& Iqba. L., 2006. The medical value of goat milk. Janadi- ul- Sani. 13, 1427.

Jaubert, G. \& Kalantzopoulos, G., 1996. Quality of goat milk for cheese and other products. Proceedings of 6th International Conference on Goats, Beijing, China. 6-11 May 1996, volume 1, 274.

Jones, R.J. \& Megarrity, R.G., 1983. Comparative toxicity responses of goats fed on Leucaena leucocephala in Australia and Hawaii. Aust. J. Agric. Res. 34, 781-790.

Hof, G., Vervoorn, M.D., Lenaers, P.J. \& Tamminga, S., 1997. Milk urea nitrogen as a tool to monitor the protein nutrition of dairy cows. J. Dairy Sci. 80, 3333-3340.

Geerts, N.E., De Brabander, D.L., Vanacker, J.M., De Boever, J.L. \& Botterman, S.M., 2004. Milk urea concentration as affected by complete diet feeding and protein balance in the rumen of dairy cattle. Livest. Prod. Sci. 85, 263-273.

Gupta, H.K. \& Atreja, P.P., 1999. Influence of feeding increasing levels of Leucaena leaf on the performance of milch goats and metabolism of mimosine and 3-hydroxy-4 (1H) pyridone. Anim. Feed Sci. Technol. 78, 159-167.

Langston University Goat Research and Extension Programs, 2000. Langston University Agricultural Research and Extension Programs. Langston. Oklahoma USA.

Laudadio, V. \& Tufarelli, V., 2010. Effects of pelleted total mixed rations with different rumen degradable protein on milk yield and composition on Jonica dairy goat. Small Rumin. Res. doi:10.1016/j.smallrumres, 2009.12.044]

Leketa, K., 2011., Milk goat feeding systems using Leucaena leucocephala in total mixed rations. MSc. (Agric.) dissertation., Faculty of Natural and Agricultural Science, University of Pretoria, South Africa.

Liener, I.E., 2003. Plant antinutritional factors/Detoxification. Encyclopedia of Food Sciences and Nutrition. Second edition. Academic Press. Massachusetts.

Maasdorp, B.V., Muchenje, V. \& Titterton, M., 1999. Palatability and effects on dairy cow milk yield of dried fodder from the forage trees Acacia boliviana, calliandra calothyrsus and Leucaena leucocephala. Anim. Feed Sci. Technol. 77, 49-59.

Meissner, H.H., 1997. Recent research on forage utilization by ruminant livestock in South Africa. Anim. Feed. Sci. Technol. 69, 103.

Mtenga, L.A. \& Shoo, R.A., 1990. Growth rate, feed intake and feed utilization of small East African goats supplemented with Leucaena leucocephala. Small Rumin. Res. 3, 9-18.

National Research Council (NRC), 2007. Nutrient requirements of Small Ruminants: Sheep, goats, cervids and New World camelids. National Academic Press. Washington, DC., USA.

Nyambati, E.M., Sollenberger, L.E. Karue, C.N. \& Musimba, N.K.R., 2006. The value of Acacia brevispica and Leucaena leucocephala Seedpods as dry season supplements for calves in dry areas of Kenya. Afr. J. Agric. Res. 1 (4), 118-124.

Peacock, C.A. 2005. A pathway out of poverty. Small Rumin. Res. 60, 179-186.

Peniche-Gonzalez, I.N., Gonzalez-Lopez, Z.U., Aguilar-Perez, C.F., Ku-Vera, J.C., Ayala-Burgos, A.J. \& SolorioSanchez, F.J., 2014. Milk production and reproduction of dual-purpose cows with a restricted concentrate allowance and access to an association of Leucaena leucocephala and Cynodon nlemfuensis. J. Appl. Anim. Res. 42, 345-351.

Richards, D.E., Brown, W.F., Ruegsegger, G. \& Bates, D.B., 1994. Replacement value of tree legumes for concentrates in forage-based diets. II. Replacement value of Leucaena leucocephala and Gliricidia sepium for lactating goats. Anim. Feed Sci. Technol. 46, 53-65.

Rubanza, C.D.K., Shem, M.N., Bakengesa, S.S., Ichinohe, T. \& Fujihara, T., 2007. Effect of Acacia nilotica, A. polyacantha and Leucaena leucocephala leaf meal supplementation on performance of Small East African goats fed native pasture hay basal forages. Small Rumin. Res. 70, 165-173.

SAS Institute INC. 2004. Uses guide version 9.1. Statistical Analysis Systems Institute, USA.

Sastry, M.S. \& Singh, R., 2008. Toxic effects of subabul (Leucaena leucocephala) on thyroid and reproduction of female goats. Indian J. Anim. Sci. 78 (3), 251-253.

Santucci, P.M., Branca, A., Napoleone, M. Bouche, R., Aumont, G., Poisot, F. \& Alexandre, G., 1991. In: P. Morand-Fehr (ed). Goat Nutrition. Pudoc, Wageningen. ISBN 90-220-1009-0. pp. 240-255.

Sethi, P. \& Kulkarni, P.K., 1995. Leucaena leucocephala: a nutrition profile. Food and Agriculture Organization of the United Nations.

Schepers, A.J. \& Meijer, R.G., 1998. Evaluation of the utilization of dietary nitrogen by dairy cows based on urea concentration in milk. J. Dairy Sci. 81, 579-584.

Shinde, A.K., Sankh, S.K., Bhatta, R. \& Verma, D.L., 2000. Seasonal change in nutrient intake and its utilization by range goats in a semi-arid region of India. J. Agric. Sci. 135, 429-436.

Steinshamn, H., 2010. Effect of forage legumes on feed intake, milk production and milk quality - a review. Animal Science Papers and Reports 28 (3), 195-206.

Stella, A.V., Paratte, R., Valnegri, L., Cigalino, G., Soncini, G. Chevaux, E., Dell'Orto, V. \& Savoini, G., 2007. Effect of administration of live Saccharomyces cerevisiae on milk production, milk composition, blood metabolites, and faecal flora in early lactating dairy goats. Small Rumin. Res. 67, 7-13.

Waipanya, S. \& Srichoo, C., 1999. Utilization of Leucaena leucocephala as dry season protein supplement for dairy cattle in southern Thailand. Integrated Crop Livestock Production Systems and Fodder Trees. Phillippine. FAO. 